\title{
Ekonomik Küreselleşme Sofistike Mamül Üretimini Etkiler mi? : Güney Kore Örnekleminde Ampirik Bir Analiz
}

\author{
Muhlis CAN \\ Yrd. Doç. Dr., Hakkari Üniversitesi \\ iiBF, Ekonomi ve Finans Bölümü \\ muhliscan@hu.edu.tr
}

Ekonomik Küreselleşme Sofistike Mamül
Üretimini Etkiler mi? : Güney Kore
Örnekleminde Ampirik Bir Analiz

\section{Özet}

Son dönemde iktisat literatüründe yapılan çalışmalarda yapısal dönüşümün önemi sıklıkla vurgulanmaktadır. Bu dönüşümü başarmış ülkelerin başında Güney Kore gelmektedir. Bu çalışmada, üretimde sofistike mamül üretim düzeyini temsil eden ekonomik kompleksite ile ekonomik küreselleşme ilişkisinin Güney Kore örnekleminde incelenmesi amaçlanmıştır. Çalışmada birim kök testleri yapısal kırılmaları göz önünde bulunduran Zivot ve Andrews (1992), Lee ve Strazicich (2003) yaklaşımlarıyla gerçekleştirilmiştir. Eş bütünleşme analizinde Maki (2012) yaklaşımı diğer taraftan; uzun ve kısa dönem analizlerinde Tam Modifiye Edilmiş En Küçük Kareler (FMOLS) yöntemi kullanılmıştır. Çalışma sonucunda ekonomik küreselleşmenin ekonomik kompleksiteyi pozitif şekilde etkilediği bulgusuna ulaşılmıştır. Hata düzeltme modelinde ise hata teriminin negatif ve istatistiki olarak anlamlı olduğu tespit edilmiştir.

Anahtar Kelimeler: Ekonomik Kompleksite, Ekonomik Küreselleşme, Sofistike Üretim, Yapısal Kırılma, Eşbütünleşme

JEL SInıflaması: E23, F10, F14, F60

\author{
Does Economic Globalization Effect \\ Sophisticated Product Manufacturing? : An \\ Empirical Study in South Korea
}

\begin{abstract}
The importance of structural transformation is often emphasized in recent studies in economic literature. One of the leading countries managed to achieve this transformation is South Korea. In this study, it is aimed to investigate the relationship between economic complexity representing the level of sophisticated product manufacturing and economic globalization in the sample of South Korea. In unit test analysis Zivot and Andrews (1992), Lee and Strazicich (2003), taking account structural breaks, have been employed. In cointegration analysis Maki (2012) approach and in short and long term analysis Fully Modified Ordinary Least Square Method (FMOLS) have been used. It has been conculuded that economic globalization has posive effect on economic complexity. In the error correction model, it has been observed that error correction term is negative and statistically significant.
\end{abstract}

Keywords: Economic Complexity, Economic Globalization, Sophisticated Production, Structural Break, Cointegration

JEL Classification: E23, F10, F14, F60

\section{Giriş}

Son dönemde iktisat yazınında yapılan çalışmalarda, az gelişmiş ve gelişmekte olan ülkelerin ekonomilerinin yapısal dönüşüme ${ }^{1}$ olan ihtiyacı sıklıkla vurgulanmaktadır.

\footnotetext{
${ }^{1}$ Çalışmada yapısal dönüşüm, yapısal reformlarla değişimli olarak kullanılacaktır.
} 
Bunun altında yatan en önemli sebep, sürdürülebilir büyüme rakamlarının bu ülke gruplarında yakalanamıyor olmasıdır. Mevcut üretim yapıları itibariyle bu ülkeler gelir esnekliği düşük, emek yoğun ürünler üretip ihraç etmektedir. Fakat bu ürünlerin ülke ekonomisine sağladıkları katma değer artışı oldukça düşük düzeydedir. Ayrıca, bu sektörler kısıtlı bilgi, beceri ve verimlilik düzeyine sahip olduklarından dolayı, diğer sektörlere yayılım etkileri düşük seviyede kalmaktadır. Bu doğrultuda, ekonomide yapılacak yapısal reformlar büyük önem taşımaktadır. Üretimde başarılacak yapısal dönüşüm, ilgili ülkenin/ülkelerin daha hızlı büyümesini sağlayacaktır (Haussmann vd. 2007: 2).

Günümüzde kimi ülkelerin daha zengin, kimi ülkelerin daha fakir olmasının altında yatan en önemli etken, üretim faktörlerini verimli alanlara yönlendirme başarılarıdır. Örneğin; nüfus olarak Singapur, Pakistan ile karşılaştırıldığında 34 kat daha küçük bir ülkedir. Her iki ülke de ortalama olarak 133 çeşit ürün ihraç etmektedir. Kişi başına düşen gelir açısından karşılaştıııldığında ise ortaya çarpıcı sonuçlar çıkmaktadır. Singapur, Pakistan'a göre 38 kat daha zengin bir ülke konumundadır. Bunun altında yatan en önemli etken yapısal dönüşümden kaynaklı olan "bilgi" faktörüdür (Hausmann vd. 2011: 22). Yapısal dönüşümü sağlayan ülkelerin ekonomik olarak oldukça büyük işler başardığı söylenebilir. Bu başarıyı sağlayan ülke grubunun başında ise Asya Kaplanları olarak adlandırılan ülkeler gelmektedir (McMillan vd. 2014: 11). Özellikle, Güney Kore'nin son çeyrek asırdır yapmış olduğu büyük dönüşüm, değişik ekonomi çevrelerince takdir edilmektedir. ${ }^{2}$ Bu süreçte Güney Kore tarımsal üretime olan bağımlıı̆̆ını azaltıp, imalat sanayisine yönelmiştir (Felipe vd. 2013: 792). Güney Kore, 1960 'lı yıllarla ortaya koymuş olduğu kalkınma planı dahilinde imalat, kimya, ağır çelik ve metal, gemicilik, makine ve elektronik alanlarına yoğunlaşmıştır. Bunların her biri yüksek katma değer üreten sektörlerdir. Bu doğrultuda Güney Kore, sektörlerin birbirlerinin tamamlayıcısı olacak politikalar da geliştirmiştir. Örneğin, yapılan eğitim faaliyetleri ile yüksek nitelikli işgücünün yetiştirilmesi bunlardan biridir. Yetiştirilen nitelikli işgücü yukarıda bahsi geçen tüm sektörlerde çalışabilme olanağına kavuşmuştur. Ayrıca, belirli endüstrilerde faaliyet gösteren firmalara kredi imkânlarının tanınması, araştırma ve geliştirme (Ar-Ge) merkezlerinin kurulması uygulanan politikalardan diğerlerini oluşturmaktadır (Jankowska vd. 2012). Güney Kore'nin geçirmiş olduğu süreci üç ana bölümde incelemek mümkündür. 1960 ve 1970 'li yılları kapsayan imitasyon süreci, 1980 'li yılları kapsayan yapısal dönüşüm süreci ve 1990 'lı yıllarla birlikte ortaya çıkan inovasyon süreci (OECD, 2009: 173-176). 1960-1970 yılları arasında gerçekleşen imitasyon sürecinde emek yoğun sektörlerin ağırlıkta olduğu görülmektedir. Bu süreçte yabancı yatırımlar ve teknolojinin ithali ile sanayileşme politikaları desteklenmiştir. Yapısal dönüşüm sürecinde ise özel sektörün kendi Ar-Ge sistemini oluşturması teşvik edilmiştir. İnovasyon sürecinde ise büyük işletmeler yerine daha dinamik yapıya sahip olan küçük ve orta büyüklükteki işletmelerin desteklenmesi

${ }^{2}$ Yapısal dönüşüm süreci için Tablo 1'e bakınız.

ESKişeHir OSMANGAZi ÜNIVERSiTESi IiBF DERGISi 
sağlanmıştır (Aslanhan ve Kurtsal, 2010). Güney Kore'nin ortaya koyduğu başarı hikâyesinin ardında pek çok parametre olduğu bir gerçektir. Bunlardan birinin de ekonomik küreselleşme olduğu söylenebilir.

Tablo 1: Güney Kore Yapısal Dönüşüm Süreci

\begin{tabular}{|c|c|c|c|c|}
\hline & $1960-1980$ & 1980-1990 & $1990-2000$ & 2000 ve sonrası \\
\hline 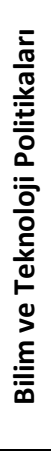 & $\begin{array}{l}\text { *ilk devlet araştırma } \\
\text { enstitüsü Kore Bilim ve } \\
\text { Teknoloji Enstitüsü } \\
\text { (KIST) ve Bilim ve } \\
\text { Teknoloji Bakanlı̆̆ı'nın } \\
\text { kurulması } \\
\text { *Bilim ve Teknoloji } \\
\text { Teşvik Yasasının } \\
\text { yürürüleğe girmesi } \\
\text { (1967) }\end{array}$ & $\begin{array}{c}\text { *Ulusal Ar-Ge } \\
\text { Programı (1982) } \\
\text { *“Daedeok Science } \\
\text { Town” kurulması } \\
\text { *Özel firmaların } \\
\text { Ar-Ge için teşviki } \\
\text { (vergi teşvikleri, } \\
\text { finansal teşvikler) }\end{array}$ & $\begin{array}{c}\text { *Ulusal Bilim ve } \\
\text { Teknoloji Konseyinin } \\
\text { kurulması } \\
\text { *Beş yıllık inovasyon } \\
\text { planı (1997) } \\
\text { *Bilim ve Teknoloji } \\
\text { vizyonu } 2025 \text { (1999) } \\
\text { *Üniversite } \\
\text { araştırmalarının } \\
\text { teşviki }\end{array}$ & $\begin{array}{c}\text { *ilk ulusal } \\
\text { teknoloji yol } \\
\text { haritasının } \\
\text { hazırlanması } \\
\text { *Bilim ve } \\
\text { Teknoloji } \\
\text { Bakanlığı'nın } \\
\text { yeniden } \\
\text { yapılandırılması }\end{array}$ \\
\hline 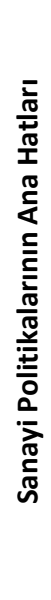 & $\begin{array}{c}\text { *1960'lar: İthal ikameci } \\
\text { sanayilerin gelişimi. } \\
\text { Ucuz emek sayesinde } \\
\text { taım ve tekstil gibi } \\
\text { sektörlerin ön planda } \\
\text { olması. } \\
\text { *Doğrudan yabancı } \\
\text { yatırımlar ve teknoloji } \\
\text { transferi } \\
\text { *1970’ler: Ağır sanayiye } \\
\text { geçiş } \\
\text { *Yerli Ar-Ge } \\
\text { kapasitesinin } \\
\text { geliştirilmesinin teşviki }\end{array}$ & $\begin{array}{l}\text { *Teknoloji yoğun } \\
\text { sektörlere kayma } \\
\text { *Tek başına } \\
\text { teknoloji transferi } \\
\text { ve araştırma } \\
\text { ensittülerinin } \\
\text { yetersiz kalması, } \\
\text { firmaların kendi Ar- } \\
\text { Ge yapılarını } \\
\text { kurmaları/geliştirm } \\
\text { elerinin teşvik } \\
\text { edilmesi }\end{array}$ & $\begin{array}{l}\text { *ileri teknoloji } \\
\text { sektörlerinde } \\
\text { gelişme } \\
\text { *Talebe yönelik } \\
\text { teknoloji geliştirme } \\
\text { sisteminin } \\
\text { güçlendirilmesi } \\
\text { *Asya Krizi ve } \\
\text { sonrasında gelen } \\
\text { düzenlemeler ve } \\
\text { yaşanan değişimler }\end{array}$ & $\begin{array}{c}\text { *Var olan ileri } \\
\text { teknoloji } \\
\text { sektörlerinde } \\
\text { ilerlemenin yanı } \\
\text { sıra biyoteknoloji } \\
\text { ve } \\
\text { nanoteknolojiye } \\
\text { giriş } \\
\text { *Geleneksel KOBi } \\
\text { yapılanmasından } \\
\text { farklı Ar-Ge } \\
\text { temelli KOBi'lerin } \\
\text { yaygınlaşması }\end{array}$ \\
\hline
\end{tabular}

Kaynak: Aslanhan ve Kurtsal, (2010)

$\mathrm{Bu}$ çalışmanın amacı, ekonominin ne kadar bilgi, beceri içerikli üretim gerçekleştirebildiğini gösteren ekonomik kompleksite ile ekonomik küreselleşme arasındaki ilişkiyi Güney Kore örnekleminde ortaya koymaktır. Bu doğrultuda, öncelikle teorik bölümde ekonomik kompleksite ve ekonomik küreselleşme ile ilgili bilgi verilecek, sonrasında ise ampirik uygulamaya geçilecektir. Son bölümde ise elde edilen bulgulardan hareketle politika önerileri sunulacaktır. 


\section{Teorik Altyapı}

Lall'e (2000) göre ülkelerin ürettikleri mamüller, ülkenin sahip olmuş olduğu üretim faktörlerinin niteliği hakkında bilgi çıkarımına imkan vermektedir. Eğer ülke bilgi, beceri ve verimli (sofistike) ${ }^{3}$ mamül üretebiliyorsa, bu durumdan ülkenin üretim için gerekli olan beşeri sermayesinin, fiziksel altyapısının ve kurumsal kalite düzeyinin iyi durumda olduğu sonucunu çıkarmak mümkün hale gelmektedir. Farklı bir deyişle, böyle bir üretim gerçekleştirilebiliyor olması, ülkenin kompleks bir üretim (ekonomik kompleksite) yapısının olduğunun bir göstergesidir (Yameogo vd., 2014: 398). Ekonomik kompleksite, bir ülkenin ürettiği ürünlerin bilgi, beceri ve kompleks içeriği şeklinde tanımlanır (Erkan ve Yıldırımcı, 2015: 525). Bu bilgi, beceri ve kompleks içerik bir bütün olarak "yetenek" olarak adlandırılır. Bir ülkenin yeteneğinin üç farklı unsurdan oluştuğu söylenebilir. Bunlardan ilki fiziki ve beşeri sermaye, hukuk sistemi, kurumsal kaliteden oluşmaktadır. İkincisi, bireylerin bir firma etrafında ortaya koydukları çalışma pratiği ve know-how'dur. Son olarak organizasyon becerisi gelmektedir. Organizasyon becerisi ise birçok insanı içeren faaliyetlerin yönetim başarısı olarak ifade edilebilir (Felipe vd. 2012: 37).

Ekonomik kompleksitenin başarıya ulaşmasının farklı gereklilikleri vardır. Çünkü her ürün için gerekli bilgi, fiziki mal, aramalı, altyapı ve mülkiyet hakları farklılık göstermektedir. Bir firmanın, yeni bir mamül üretmeye karar vermesi durumunda farklı problemlerle karşılaşması mümkün görünmektedir. Bu doğrultuda firmanın yeni üreteceği mamül için gerekli girdiyi piyasada mevcut firmalardan temin etmesi gerekecektir. Firmanın ilgili ürünü üretebilmesi, piyasada benzer içerikli ürün üreten firmaların varlığına bağlıdır. ${ }^{4}$ Yani üretilecek mamül mevcut ürünlere ne kadar yakınsa, bu durumda yeni ürünün ortaya çıkması o denli muhtemel hale gelecektir (Hausmann ve Klinger, 2009: 9). Örneğin, C, E, P, T, E, L, E, F, O, N, U harflerinin her biri bir girdiyi (bilgi ve yetenek) temsil etmektedir. Bu harflerden yola çıkarak UN, EL, ON, TEL, FON, TELEF, TELEFON, CEP TELEFONU kelimeleri (ürün) türetilebilmektedir. Elde edilen kısa kelimeler, içerik olarak daha az bilgi ve yeteneğin olduğunun bir göstergesi iken, uzun kelimeler ise daha kompleks (bilgi, beceriği yoğun ve verimli) ürünü temsil etmektedir. ${ }^{5}$ Ülkenin sahip olmuş olduğu girdi çeşitliliği ne kadar fazla ise daha fazla ürün (kelime) kombinasyonu ortaya çıkacaktır. Bu durum, ekonomik kompleksitenin en önemli yapı taşıdır (Hausmann vd., 2011: 15). Hausmann ve Klinger (2009) tam olarak bunu ifade etmektedir. Yani CEP TELEFONU kelimesi (ürününü) türetmek istenen bir yerde eğer $T$ harfi (bilgi, beceri, girdi) yok ise, ilgili kompleks kelime (ürün) ortaya çıkmayacaktır. Fakat sahip olunan bilgi ve beceri tek başına yeterli değildir. Ayrıca, bu bilgi ve becerileri

\footnotetext{
3 "Sofistike" kelimesi çalışmanın bundan sonraki aşamalarında "kompleks" olarak kullanılacaktır.

${ }^{4}$ Eğer mevcut piyasada yeni mamüle benzer içerikte üretim yapılıyor ise bu durumda firmanın ihtiyaç duyduğu ara girdiyi, işgücünü temin etmesi kolaylaşır.

${ }^{5}$ Hausmann vd. (2011: 20) örneğinden yola çıkarak yazar tarafından hazırlanmıştır.
} 
bir araya getirecek ve kullanacak piyasaların ve organizasyonların olması da gerekmektedir (Hausmann vd. 2011: 7).

Ürünler farklı içerikteki girdilerin bir araya gelmesi ile oluşur. Bu girdilerin her biri "yetenek" olarak tanımlanabilir. Kompleks ürünlerin ortaya çıkmasında iki faktör devreye girmektedir. Bunlardan ilki üretim faktörlerin yetenekleri, diğeri ise üretim için gerekli olan teknoloji düzeyidir (Hausmann ve Hidalgo, 2011: 310). Ülkenin sahip olmuş olduğu yetenek (bilgi ve beceri düzeyi) ne kadar çeşitli ise, bu durum diğer ülkelerden farklılaşmasına neden olacaktır. Ayrıca, yetenek çeşitliliği ilgili ülkenin ekonomik kompleksitesinin de artmasına katkı sağlayacaktır. Eğer ülkenin ürettiği ürünler birçok ülke tarafından üretilebiliyorsa, ilgili ülkenin sahip olmuş olduğu bilgi ve beceri düzeyinin dikkat çekici olmadığı sonucunu çıkarmak mümkündür (Hidalgo, 2009).

Ülkelerin ekonomik kompleksitelerine pozitif katkı sağlayacak unsurların başında Doğrudan Yabancı Yatırımların (DYY) geldiği söylenebilir. DYY'nin gittiği ülkede verimlilik düzeyinde artış sağlaması, işgücünün niteliği arttırması, ülke ekonomisini dünya ekonomi ile uyumlu hale getirmeye yardımcı olması (Delice ve Birol, 2011: 2-3), know-how'u beraberlerinde getirmesi beklenir (Javorcik ve Spatareanu, 2005: 45). DYY'ler ileri teknoloji ve yeni girdiler ile üretim fonksiyonuna önemli katkı sağlar (Wang vd., 2004: 569). Yatırımların gerçekleşmesi ile yerli şirketler ile DYY arasında tamamlayıcılık etkisi ortaya çıkar (Apergis vd., 2006: 386). Bunun yanında yerel firmalar DYY'ler tarafından üretilen ürünleri taklit ederek ürün kalitelerini arttırabilirler. Ayrıca, yerel şirketler DYY'lere ait firmalarda çalışan işgücünü bünyelerinde katarak yeni üretim metodları hakkında bilgi sahibi olabilirler (Gorodnichenko vd. 2007: 58).

Ekonomik kompleksite için Ar-Ge faaliyetleri büyük önem taşımaktadır (Erkan ve Yıldırımcı, 2015: 525). Ar-Ge faaliyetleri özünde yüksek maliyetler içermektedir. (Blomström vd. 2000: 15) DYY'ler yeni ürünler için Ar-Ge harcaması gerçekleştirirler (Karluk, 2003: 505). Bu durum ekonomik kompleksiteyi pozitif olarak etkiler. Fakat sadece DYY'lerin yapacağı Ar-Ge yeterli olmayabilir. Bu durumda finansal gelişme büyük önem taşımaktadır. Çünkü, yerel şirketlerin Ar-Ge maliyetlerini kendi bütçeleriyle karşılama imkanı oldukça zordur. Finansal gelişmenin sağlanması ile ülkedeki bankacılık faaliyetleri artar. Bu durum, yerli üreticilerin yeni teknolojik ürün üretmesinin yolunu açar. Finansal gelişme ile sermaye maliyetinde önemli düşüşler ortaya çıkar (Prasad vd. 2003: 2, 14). Bu da firmalara üretim için gerekli olan makine, ileri teknolojiyi transfer etme imkanı sağlar (Shahbaz vd. 2013: 11). DYY'lerin finans alanında gerçekleştirdikleri yatırımlar göz önünde bulundurulduğunda, bu yatırımların piyasada kredi genişlemesini pozitif etkilemesi olasıdır.

Ekonomik kompleksiteyi arttırabilecek bir diğer unsur da liberal ekonomik politikalardır. Bu sayede firmalar dışarıdan daha fazla ara malı temin etme imkanı elde ederler (Collier ve Venables, 2007: 1331). Dış ticaret sayesinde ülkeler teknoloji transferi imkânına kavuşur. Bu durumun gerçekleşmesi ile diğer sektörlerden durumdan istifade ederler. Diğer bir deyişle yeni üretim olanaklarının önü açılmış olur 
(Wang vd. 2004: 568). Tarifeler ile ticaretin zorlaştırılması ülkenin ortaya koyabileceği potansiyel ürünlere engel teşkil edecektir. Diğer bir deyişle, eldeki mevcut bilgi ve becerilerden yoksun olan ülkeler liberal ekonomik politikalarla bu açıklarını gidererek daha kompleks ürünler ortaya koyabilirler.

Yukarıda ekonomik kompleksiteye etki edebilecek tüm etkenler tek bir endeksle ifade edilebilmektedir. Bu endeks Dreher (2006) tarafından ortaya konan KOF ekonomik küreselleşme endeksidir. Endeks 0 ile 100 arasında değişmektedir. Endeks değerinin 100 yaklaşması, ilgili ülkenin ekonomik küreselleşmeye iyi entegre olduğunun bir göstergesidir.

Tablo 2: Ekonomik Küreselleşme Endeksinin Bileşenleri

1-) Ticari ve Sermaye Akımları

a-) Dış Ticaret ( Gayrı Safi Yurt İçi Hasıla’nın yüzdesi)

b) Doğrudan Yabancı Yatırımlar (Gayrı Safi Yurt İçi Hasıla'nın yüzdesi)

c-) Portföy Yatırımları (Gayrı Safi Yurt İçi Hasıla'nın yüzdesi)

d-) Yabancı Uluslara Ödenen Gelir (Gayrı Safi Yurt İçi Hasıla'nın yüzdesi)

2-) Kısıtlamalar

a-) Gizli İthalat Engelleri

b-) Ortalama Tarife Oranı

c-) Uluslararası Ticaret Üzerindeki Vergiler (Cari Gelirin yüzdesi)

d-) Sermaye Hesabı Kısıtlamaları

Kaynak: Dreher, 2006: 1094.

\section{Güney Kore Ekonomisinin Kompleksitesi}

Bu bölümde Güney Kore ekonomisinin kompleksitesi incelenecektir. Şekil 1'de yer alan grafik incelendiğinde, 1970'li yılların başında endeks değerinin 1'in altında seyrettiği görülmektedir. İzleyen iki dönemde önemli sıçrama yaşansa da bu yükselişin istikrarlı olduğu söylenemez. 1980'li yıllardan itibaren belirli bir düşüş yaşandığı açıkça görülmektedir. Fakat 1990'lı yılların ortasından itibaren trendin süreklilik izlediği tespit edilmiştir. Bu doğrultuda ilgili süreçten sonra Güney Kore ekonomisinin kompleksitede istikrar yakaladığı söylenebilir. 
Şekil 1: Güney Kore Ekonomik Kompleksitesi (1970-2012)

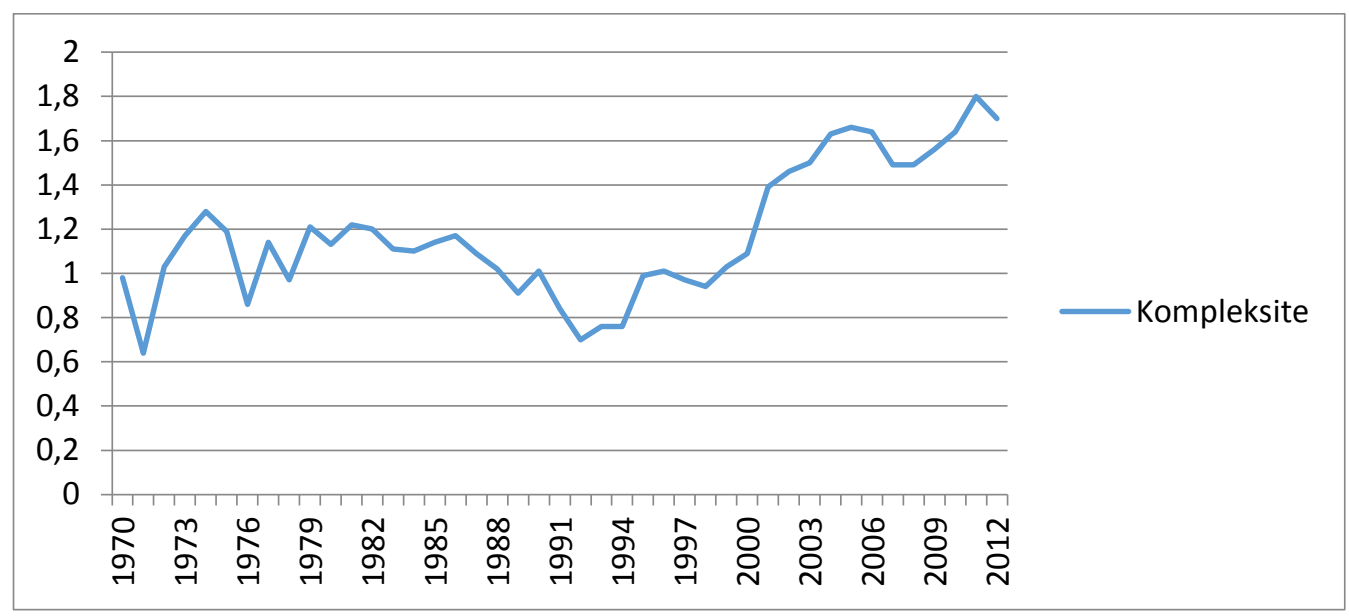

Not: Atlas Media veri tabanından elde edilen endeks yoluyla yazar tarafından oluşturulmuştur.

Fakat resmin daha netleşmesi için son dönemde Güney Kore'nin dünya ekonomik kompleksite endeksindeki yerine göz atmakta fayda görülmektedir. Tablo 2'den de anlaşılacağı üzere 2010, 2011, 2012 yıllarında Güney Kore ürettiği ürünlerde yüksek beceri gerektiren ürünlerde uzmanlaştığı anlaşılmaktadır. Güney Kore, dünya sıralamasında 2010 yılında 7. sırada iken 2011 ve 2012 yıllarında 5. sırada yer almıştır.

Tablo 3: Ekonomik Kompleksite Dünya Sıralaması

\begin{tabular}{|c|c|c|c|c|c|c|c|c|}
\hline Sıra & & & Sıra & & & Sıra & & \\
\hline (2010) & Ülkeler & $\mathrm{ECl}$ & (2011) & Ülkeler & $\mathrm{ECl}$ & (2012) & Ülkeler & $\mathrm{ECl}$ \\
\hline 1 & Japonya & 2.10 & 1 & Japonya & 2.31 & 1 & Japonya & 2.23 \\
\hline 2 & İsviçre & 1.87 & 2 & İsviçre & 2.04 & 2 & İsviçre & 1.97 \\
\hline 3 & Almanya & 1.85 & 3 & Almanya & 1.96 & 3 & Almanya & 1.84 \\
\hline 4 & İsveç & 1.69 & 4 & İsveç & 1.86 & 4 & İsveç & 1.71 \\
\hline 5 & Avusturya & 1.68 & 5 & Güney Kore & 1.80 & 5 & Güney Kore & 1.70 \\
\hline 6 & Finlandiya & 1.66 & 6 & Avusturya & 1.80 & 6 & $\begin{array}{c}\text { Çek } \\
\text { Cumhuriyeti }\end{array}$ & 1.62 \\
\hline 7 & Güney Kore & 1.64 & 7 & $\begin{array}{c}\text { Çek } \\
\text { Cumhuriyeti }\end{array}$ & 1.80 & 7 & İngiltere & 1.61 \\
\hline 8 & $\begin{array}{c}\text { Çek } \\
\text { Cumhuriyeti }\end{array}$ & 1.62 & 8 & Finlandiya & 1.73 & 8 & Finlandiya & 1.59 \\
\hline 9 & Singapur & 1.58 & 9 & İngiltere & 1.57 & 9 & Singapur & 1.59 \\
\hline
\end{tabular}




\begin{tabular}{lllllllll}
\hline 10 & Ingiltere & 1.57 & 10 & ABD & 1.54 & 10 & Avusturya & 1.57 \\
\hline
\end{tabular}

Not: Atlas Media veri tabanından elde edilen verilerden hareketle yazar tarafından derlenmiştir.

\section{Literatür Taraması}

Ekonomik kompleksite literatürü incelendiğinde, konunun farklı kapsamlarda ele alındığı tespit edilmiştir. Örneğin; Hausmann vd. (2007) 1992-2003 yılları için farklı ülke örneklemlerinde yaptıkları çalışmada ürün içeriklerinin (bilgi ve beceri düzeylerinin) büyümeye etkisini incelemişleridir. Elde edilen bulgular neticesinde yüksek verimli ürün ihracatının ülkenin büyümesini hızlandırdığı sonucuna ulaşmışlardır. ${ }^{6}$ Poncet ve Waldemar (2013), Çin'de yer alan 200 şehrin ekonomik kompleksitesinin büyümeye etkisini incelemişlerdir. 1997-2009 yıllarını kapsayan çalışma sonucunda ekonomik kompleksitenin büyümeye pozitif katkı sağladığı sonucuna ulaşmışlardır. Felipe vd. (2012) 124 ülke örnekleminde yaptıkları çalışmada, ihracatı yapılan ürünlerde kompleks ürün payının kişi başına düşen gelir artışıyla beraber artacağı sonucuna ulaşmışlardır.

Hidalgo (2009), 1962-2000 yılları arasında Brezilya, Endonezya, Türkiye, Tayland, Güney Kore, Singapur ve Çin'in ekonomik kompleksitesinin, gözlemin ilk dönemine göre diğer ülkelerle karşılaştırıldığında önemli mesafe kat ettiği sonucuna varmıştır. Bu ülkeler ilgili süreçte bilgi ve beceri yoğun ürünler üretmeye başlamışlardır. Fakat Brezilya, Endonezya ve Türkiye için durum farklılık arz etmektedir. Bu ülkeler, ilgili dönemde üretim yapılarını değiştirme çabasında olsalar dahi, bu çabaların daha kompleks ürün üretimine henüz istenilen düzeyde katkı sağlamadığı vurgulanmıştır. Erkan ve Yıldırımcı (2015) Türkiye örnekleminde yaptıkları istatistiksel analizde Türkiye'nin emek yoğun üretimde yoğunlaştığı tespit etmiştir. Çalışma sonucunda, ekonomik kompleksite artışının kompleks mamül üretiminden geçtiği vurgulanmıştır. Hartmann vd. (2015) 1996-2001 ve 2002-2008 yılları arasında iki alt dönemde ekonomik kompleksite ve gelir eşitsizliğini incelemişlerdir. Çalışma sonucunda ekonomik kompleksite ve gelir dağılımı arasında negatif bir ilişkinin olduğu bulgusu elde edilmiştir. Literatüde ekonomik kompleksitenin belirleyicilerine yönelik tek çalışmanın Daude vd. (2015) tarafından gerçekleştirildiği tespit edilmiştir. 103 ülke örnekleminde yapılan çalışmada, doğrudan yabancı yatırımlar, liberal ekonomik politikalar (dışa açıklık), finansal gelişme kurulan modelde açıklayıcı değişken olarak kullanılmıştır. Her üç değişkenin de ekonomik kompleksitenin önemli bir belirleyicisi olduğu sonucuna ulaşılmıştır.

Uluslararası literatür bağlamında ele alındığında KOF küreselleşme endeksi ile yapılmış birçok ampirik çalışmaya rastlamak mümkündür. Çalışmaların ağırlıklı olarak küreselleşme ve büyüme ilişkisine yoğunlaştığı görülmektedir. Örneğin Dreher (2006),

${ }^{6}$ Bu çalışmada ekonomik kompleksite endeksinin de temelini oluşturan PRODY endeksi kullanılmıştır. ESKişEHIR OSMANGAZi ÜNIVERSITESi IiBF DERGisi 
Shaikh ve Shah (2008), Chang ve Lee (2010), Chang ve Lee (2011), Rao ve Vadlamannati (2011), Villaverde ve Maza (2011), Chang vd. (2011), Ali ve Imai (2013) farklı ülke/ülke grubu örnekleminde yaptıkları çalışma sonucu küreselleşmenin ekonomik büyüme üzerinde pozitif etkisinin olduğu sonucuna ulaşmışlardır. Türkçe literatürde KOF küreselleşme endeksi kullanarak ampirik uygulama içeren üç çalışma olduğu tespit edilmiştir. Bu çalışmalarda Açıkgöz ve Mert (2011), Doğan ve Can (2016) küreselleşmenin büyümeye etkisi üzerine yoğunlaşırken, Yanar ve Şahbaz (2013) küreselleşmenin gelir eşitsizliğine etkisini incelemiştir. Bu doğrultuda çalışmanın, ele alındığı dönem itibariyle Türkçe literatürde KOF ekonomik küreselleşme ve ekonomik kompleksite ilişkisini inceleyen ilk çalışma olduğu düşünülmektedir. Çalışma ayrıca Daude vd. (2015) çalışmasından da farklılaşmaktadır. Il gili çalışmada ekonomik küreselleşmenin bileşenleri ayrı ayrı teste tabii tutulurken, bu çalışmada bir bütün olarak değerlendirilmektedir.

\section{Veri ve Yöntem}

Çalışmada, ekonomik kompleksite (EKE) ve ekonomik küreselleşme (ECO) arasındaki ilişki Güney Kore örnekleminde $1970-2012^{7}$ yılları arası için incelenmiştir. EKE serisi Atlas Media veri tabanından, ECO serisi ise KOF Globalization veri tabanından elde edilmiştir. Eş bütünleşme analizinden önce seriler Zivot ve Andrews (1992), Lee ve Strazicich (2003) yapısal kırılmalı birim kök analizine tabi tutulmuştur. Eş bütünleşme analizi ise çoklu yapısal kırılma altında eş bütünleşme ilişkisini araştırmaya izin veren Maki (2012) ile gerçekleştirilmiştir. Ardından serilere ait uzun ve kısa dönem analizleri Tam Modifiye Edilmiş En Küçük Kareler Yöntemi (FMOLS) ile incelenmiştir.

Çalışmada kullanılacak ana model aşağıdaki şekilde ifade edilebilir.

$$
E K E_{t}=\alpha_{0}+\alpha_{1} E C O_{t}+\varepsilon_{t}
$$

Denklemde yer alan EKE; ekonomik kompleksite endeksini, ECO; ekonomik küreselleşmeyi, $\varepsilon_{t}$ ise modele ait hata terimini temsil etmektedir.

\subsection{Birim Kök Testi}

Serilerin birim kök sınaması Zivot ve Andrews (1992), Lee ve Strazicich (2003) yaklaşımları ile test edilmiştir. Zivot ve Andrews (1992) tek kırılmayı, Lee ve Strazicich (2003) ise çift kırılmayı göz önünde bulundurmaktadır. Her iki teste ait hipotez;

$\mathrm{H}_{0}$ : Seri durağan değildir, birim kök vardır.

$\mathrm{H}_{1}$ : Seri durağandır, birim kök yoktur.

şeklindedir.

\footnotetext{
7 İlgili dönem aralığının seçilmesinin nedeni KOF Küreselleşme Endeksinin 1970-2012 tarihleri arasını kapsamasından ileri gelmektedir.
} 
Tablo 4'ten anlaşıldığı gibi düzey değerleri ile yapılan testler sonucunda elde edilen istatistik değerlerinin tümünün kritik değerin sağında kaldığı, yani kabul bölgesine düştüğü görülmektedir. Bu doğrultuda $\mathrm{H}_{0}$ hipotezinin reddedilmesi mümkün değildir. Diğer bir deyişle, seriler birim kök barındırmaktadır. Fark işlemi neticesinde ise elde edilen istatistik değerlerinin kritik değerlerin soluna, yani red bölgesine düştüğü tespit edilmiştir. Farklı bir deyişle $\mathrm{H}_{0}$ hipotezi reddedilerek serilerin durağan olduğuna karar verilmiştir. Bu durum ayrıca Maki (2012) eş bütünleşme testinin de bir ön koşuludur.

\section{Tablo 4: Birim Kök Sınaması Sonuçları}

\begin{tabular}{|c|c|c|c|c|c|}
\hline Değişken & $\begin{array}{c}\text { Düzey } \\
\text { Değerleri }\end{array}$ & Fraksyon & Kırılma Tarihleri & $\begin{array}{l}\text { Birinci } \\
\text { Farkları }\end{array}$ & Fraksyon \\
\hline $\operatorname{EKE}_{(Z A, 1992)}$ & $\begin{array}{r}-5.141 \\
{[-5.34]} \\
\end{array}$ & 0.698 & 1999 & $\begin{array}{l}-5.960 \\
{[-5.34]} \\
\end{array}$ & 0.548 \\
\hline $\operatorname{EKE}_{(L S, 2003)}$ & $\begin{array}{r}-2.328 \\
{[-4.54]}\end{array}$ & $0.163-0.209$ & $1976-1978$ & $\begin{array}{l}-4.991 \\
{[-4.54]}\end{array}$ & $0.381-0.857$ \\
\hline $\mathrm{ECO}_{(\mathrm{ZA}, 1992)}$ & $\begin{array}{l}-4.502 \\
{[-5.34]}\end{array}$ & 0.372 & 1985 & $\begin{array}{l}-6.875 \\
{[-5.34]}\end{array}$ & 0.881 \\
\hline $\mathrm{ECO}_{(\mathrm{LS}, 2003)}$ & $\begin{array}{l}-4.208 \\
{[-4.54]}\end{array}$ & $0.372-0.651$ & $1985-1997$ & $\begin{array}{l}-7.777 \\
{[-4.54]}\end{array}$ & $0.238-0.452$ \\
\hline
\end{tabular}

Not: Birim kök sınaması sırası yukarıdan aşağı tek kırılmalı test olan Zivot ve Andrews (1992), çift kırılmalı testler olan Lee ve Strazicich (2003) şeklindedir. Birim kök sınamasında sabitte yapısal kırılmaya izin veren model tercih edilmiştir. Zivot ve Andrews (1992) ADF, Lee ve Strazicich (2003) testlerinde LM test istatistiği kullanılmıştır. Yapısal kırılma tarihleri, düzey değerleri için yapılan test ile belirlenmiştir. Optimal gecikme uzunluğu maksimum 3 gecikme kullanılarak Akaike Bilgi Kriterine göre tespit edilmiştir. [ ] içindeki değerler \%1 önem seviyesindeki kritik değerleri ifade etmektedir.

\subsection{Eş bütünleşme Analizi}

Yapısal kırılma koşulu altında literatürde eş bütünleşemeye izin veren farklı analiz yöntemleri bulunmaktadır. Bunlar arasında en sık kullanılanlar Gregory ve Hansen (1996), Carrion-i-Silvestre ve Sanso (2006), Westerlund ve Edgerton (2006) analizleridir. Fakat bahsi geçen yöntemler ile sadece tek kırılma varsayımında eş bütünleşme analizi gerçekleştirilebilmektedir. Maki (2012) ile ise beş kırılma varsayımı altında eş bütünleşme analizi yapılabilmektedir. Maki (2012) dört farklı model ile yapısal kırılmalar altında eş bütünleşmeyi araştırmaktadır. Bu modeller;

1-) Model 0: Sabit terimde kırılma var, trendsiz model.

2-) Model 1: Sabit terimde ve eğimde kırılma var, trendsiz model.

3-) Model 2: Sabit terimde ve eğimde kırılma var, trendli model.

4-) Model 3: Sabit terimde, eğimde ve trendde kırılma var. 
Maki (2012) eş bütünleşme analizine ait hipotezler

$\mathrm{H}_{0}$ : Seriler arasında eş bütünleşme yoktur.

$\mathrm{H}_{1}$ : Seriler arasında eş bütünleşme vardır.

şeklindedir. Yapılan incelemede eğer seriler arasında eş bütünleşme olduğuna karar verilirse, kırılma tarihleri modele kukla değişken olarak eklenecek ve uzun dönem analizi gerçekleştirilecektir.

Tablo 5: Eş Bütünleşme Sonuçları

\begin{tabular}{cccccc}
\hline \multirow{2}{*}{ Modeller } & İstatistik Değeri & \multicolumn{3}{c}{ Kritik Değerler } & \multirow{2}{*}{ Kırılma Tarihleri } \\
\cline { 3 - 5 } & & $\% 1$ & $\% 5$ & $\% 10$ & \\
\hline Model 0 & $-5.613^{*}$ & -5.959 & -5.426 & -5.131 & $1978,1982,1988,2000,2008$ \\
\hline Model 1 & $-5.768^{*}$ & -6.193 & -5.699 & -5.449 & $1975,1982,1988,2000,2006$ \\
\hline Model 2 & $-8.046^{* *}$ & -6.915 & -6.357 & -6.057 & $1975,1988,1994,2000,2008$ \\
\hline Model 3 & $-11.744^{* *}$ & -8.004 & -7.414 & -7.110 & $1978,1990,1995,2000,2006$ \\
\hline
\end{tabular}

Not: Kritik değerler Maki (2012) Tablo'1 ait kritik değerlerdir. **, * sırasıyla \%1 ve \%5 anlamlılık düzeyinde eş bütünleşmenin olduğu ifade etmektedir.

Tablo 5'te görüldüğü üzere elde edilen tüm istatistik değerleri kritik değerlerin solunda, yani red bölgesinde yer almaktadır. Bu doğrultuda $\mathrm{H}_{0}$ hipotezi reddedilerek tüm modeller için seriler arasında eş bütünleşme ilişkisinin olduğuna karar verilmiştir.

\subsection{Uzun Dönem Analizi}

Seriler arasında uzun dönem analizi FMOLS ile incelenmiştir. Eş bütünleşme ilişkisinde sabit terimde kırılmanın olduğu, trendsiz model baz alınarak analiz yapılmıştır. illgili modelde yapısal kırılmanın olduğu 1978 (DU78), 1982 (DU82), 1988 (DU88), 2000 (DU00) ve 2008 (DU08) modele kukla değişken olarak dahil edilerek uzun dönem analizi gerçekleştirilmiş ve Tablo 6'da raporlanmıştır. Yapılan inceleme sonucunda ekonomik küreselleşmenin ekonomik kompleksiteye pozitif şekilde etkilediği sonucuna ulaşılmıştır. 
Tablo 6: FMOLS Uzun Dönem Analizi

\begin{tabular}{cccc}
\hline Değişken & Katsayı & t-istatistiği & Olasilık \\
\hline ECO & 0.017 & 2.795 & 0.008 \\
\hline C & 0.430 & 1.965 & 0.057 \\
\hline DU78 & 0.045 & 0.589 & 0.559 \\
\hline DU82 & -0.108 & -1.514 & 0.138 \\
\hline DU88 & -0.279 & -4.398 & 0.000 \\
\hline DU00 & 0.445 & 5.608 & 0.000 \\
\hline DU08 & 0.114 & 1.669 & 0.104 \\
\hline
\end{tabular}

Not: Gecikme değeri Akaike Bilgi Kriterine göre, bant aralığı Newey-West metoduna göre belirlenmiştir. İlgili modele ait $R^{2}$ değeri 0.85 , düzeltilmiş $R^{2} 0.82$, Jarque-Bera olasılık değeri 0.13 olarak tespit edilmiştir.

\subsection{Kısa Dönem Analizi (Hata Düzeltme Modeli)}

Hata düzeltme modeli, uzun dönem analizinde olduğu gibi FMOLS ile gerçekleştirilmiştir. Uzun dönem analizinden çekilen hata teriminin bir gecikmesi $\left(E C_{t}-\right.$ 1) modele açıklayıcı değişken olarak dahil edilmiştir. Bu doğrultuda hata düzeltme modeli aşağıdaki şekilde ifade edilebilir.

$$
\Delta E K E_{t}=\alpha_{0}++\alpha_{1} \Delta E C O_{t}+\alpha_{2} E C T_{t-1}+\varepsilon_{t}
$$

Modelde yer alan değişkenlere ait açıklamalar denklem 1'deki ile aynıdır. Farklı olarak $\Delta$, fark operatörünü temsil etmektedir.

Tablo 7: FMOLS Kısa Dönem Analizi

\begin{tabular}{cccc}
\hline Değişken & Katsayı & t-istatistiği & Olasılık \\
\hline$\Delta E C O$ & 0.020 & 2.429 & 0.020 \\
\hline $\mathrm{ECT}_{\mathrm{t}-1}$ & -0.749 & -4.561 & 0.000 \\
\hline $\mathrm{C}$ & 0.002 & 0.130 & 0.897 \\
\hline
\end{tabular}

Not: Gecikme değeri Akaike Bilgi Kriterine göre, bant aralığı Newey-West metoduna göre belirlenmiştir. İlgili modele ait $R^{2}$ değeri 0.27 , düzeltilmiş $R^{2}$ değeri 0.23 , Jarque-Bera olasılık değeri 0.88 olarak tespit edilmiştir.

Hata düzeltme modeline ait elde edilen bulgular Tablo 7'de yer almaktadır. Sonuçlardan hareketle hata düzeltme katsayısının negatif ve istatistiki olarak anlamlı olduğu görülmektedir. Bu doğrultuda, hata düzeltme mekanizmasının çalıştığı sonucuna ulaşmak mümkündür. Seriler arasında meydana gelecek bir sapma, yaklaşık iki dönem (1/0.749) sonra yeniden dengeye gelecektir. Ampirik bölümde elde edilen bulguların Daude vd.(2015) bulgularıyla örtüştüğü söylenebilir. 


\section{Sonuç ve Öneriler}

Küreselleşen dünyada üretim büyük önem taşımaktadır. Fakat ülkelerin artık ne kadar ürettiklerinden çok hangi içerikte mamül ürettikleri daha önemli hale gelmiştir. Bu çalışma üretimde bilgi, beceri ve teknoloji yoğun üretimi temsil eden ekonomik kompleksite ile ekonomik küreselleşme arasındaki ilişkiyi Güney Kore örnekleminde ortaya koymayı amaçlamıştır. Ampirik analiz bölümünde yapısal kırılmaları dikkate alan Maki (2012) eş bütünleşme testi kullanılmıştır. Eş bütünleşme analizi neticesinde ekonomik küreselleşme ve ekonomik kompleksite serilerinin uzun dönemde birlikte hareket ettiği ortaya konmuştur. Ardından uzun dönem analizi Tam Modifiye Edilmiş En Küçük Kareler yöntemiyle gerçekleştirilmiştir. Ekonomik küreselleşmeye ait katsayının pozitif ve istatistiki olarak anlamlı olduğu bulgusuna ulaşılmıştır. Bu noktadan hareketle ekonomik küreselleşmeyi oluşturan doğrudan yabancı yatırımların, dışa açıklığın, tarifelerde ortaya çıkan düşüşlerin, gizli ithalat engellerinin kaldırılmasının bir bütün olarak Güney Kore ekonomik kompleksitesine pozitif katkı sağladığı söylenebilir. İlgili katkı farklı kanallar yoluyla gerçekleşebilir. Doğrudan yabancı yatırımların beraberinde getirmiş olduğu bilgi-beceri ve yeni teknolojilerin üretimde kullanılmasının Güney Kore ekonomik kompleksitesini arttırdığı yorumu yapılabilir. Ayrıca, yabancı yatırımların finans piyasasında gerçekleşmesinin kredi hacmini genişleterek kompleksite artışını etkilediği sonucunu çıkarmak mümkün görünmektedir. Bununla birlikte dışa açıklığın artmasının, tarifelerde ortaya çıkan düşüşün ve gizli ithalat engellerinin kaldırılmasının ara girdi ve makine-teçhizatın ithalat yoluyla temin edilmesini kolaylaştırdığı söylenebilir. Bu yolla elde edilen ara girdilerin ve makine-teçhizatın yeni kompleks ürünlerin ortaya çıkmasında önemli rol oynadığı kanaatine varmak mümkün görünmektedir.

Ekonomik küreselleşmenin bileşenleri göz önünde bulundurulduğunda, gelişmekte olan ülkelerin çıkarması gereken önemli dersler olduğu görülmektedir. Doğrudan yabancı yatırımlarında artış sağlanması, finansal piyasaların gelişmesi, liberal ekonomik politikalar desteklenmesi ve tarife indirimleri ülkelerin yapısal dönüşümüne (ekonomik kompleksite artışına) önemli katkı sağlayabilir. Fakat, bu dönüşümün kısa zamanda gerçekleşmesi mümkün değildir. Bunun için uzun yıllara ihtiyaç vardır. Bu bağlamda, politika yapıcıların uzun dönem planları yaparak bunları titizlikle uygulamaları büyük önem taşımaktadır. Ekonomik kompleksite artışının bireylerin bilgi, beceri, tecrübelerinden oluştuğu göz önünde bulundurulduğunda bu sürecin birkaç yıl içerisinde başarılamayacağı yadsınamaz bir gerçektir. Özellikle eğitim alanında yapılacak reformlar ile kompleks mamül üretme kabiliyetine sahip bireyler yetişecektir. Bu açıdan, politika yapıcıların eğitimde kompleks mamül üretiminde yönelik nitelikli ve teknik elemanlar yetiştirecek politikaları devreye sokmaları gerekmektedir. Ayrıca yetiştirilen bu elemanların istihdam edileceği firmalar ve organizasyonlara da ihtiyaç olduğu aşikardır. Bu noktadan hareketle, politika yapıcıların kompleks mamül üretimine firmaları teşvik etmesi, kredi desteği sağlaması, küçük firmaların biraraya 
getirerek daha katma değerli mamül üretimine yönlendirmesi gerekmektedir. Konu az gelişmiş ülkeler bağlamında değerlendirildiğinde ise daha temel meseleler üzerinde yoğunlaşmakta fayda görülmektedir. Bu ülke grubunda üretim için en temel gereksinimlerin başında gelen altyapı problemlerinin olduğu bilinmektedir. Bu bağlamda, politika yapıcıların yollar, limanlar, köprüler vb. inşa etmeleri gerekmektedir. Bu ülke grubunun karşılaştığı bir diğer problem de beşeri sermayenin yetersiz olmasıdır. Politika yapıcıların ayrıca beşeri sermayeyi arttırıcı projeler ortaya koyması ileride ortaya konulabilecek kompleks ürünlerin temelini oluşturacaktır. Bahsi geçen iki temel problemin çözümlenmesi ekonomik küreselleşmenin önemli parçası olan yabancı yatırımların ilgili ülke grubuna daha fazla gelmesine yol açacaktır. Ayrıca yine ekonomik küreselleşmenin önemli bir parçası olan dışa açıklığın bu ülke grubuna getireceği faydanın artacağı düşünülmektedir. 


\section{Kaynakça}

Açıkgöz, Ş. ve M. Mert (2011), “Küreselleşme Ekonomik Büyümeyi Etkiliyor Mu? Türkiye Örneği", 12.Uluslararası Ekonometri Yöneylem Araştırması ve İstatistik Sempozyumu, Pamukkale Üniversitesi, Denizli, 701-716.

Ali, A. ve K. S. Imai (2013), "Crisis, Economic Integration and Growth Collapses in African Countries", Discussion Paper Series DP 2013-07, Kobe: Research Institute for Economics \& Busines Administration, Kobe University.

Apergis, N., K. P. Contantinos ve N. M. Tabakis (2006), “Dynamic Linkages between FDI Inflows and Domestic Investment: A Panel Cointegration Approach", Atlantic Economic Journal, 34(4), 385-394.

Arslanhan, S. ve Y. Kurtsal (2010) “Güney Kore İnovasyondaki Başarısını Nelere Borçlu? Türkiye İçin Çıkarımlar", TEPAV Politika Notu.

Atlas Media, http://atlas.media.mit.edu/en/, (Erişim: 15.11.2015).

Blomström, M., A. Kokko ve M. Zejan (2000), Foreign Direct Investment Firm and Host Country Strategies, Hampshire and London: Macmillan Press Ltd, New York: St.Martin's Press Inc,

Carrion-I-Silvestre, J. L. ve A. Sanso (2006), "Testing the Null of Cointegration with Structural Breaks", Oxford Bulletin of Economics and Statistics, 68(5), 623-646.

Chang, C. ve C. Lee (2010), "Globalization and Economic Growth: A Political Economy Analysis for OECD Countries", Global Economic Review, 39(2), 151-173.

Chang, C. ve C. Lee (2011), "The Partisan Comparisons for Global Effect on Economic Growth: Panel Data Analysis of Former Communist Countries and European OECD Members", Eastern European Economics, 49(6), 5-27.

Chang, C., C. Lee ve M. Hsieh (2011). “Globalization, Real Output and Multiple Structural Breaks", Global Economic Review, 40(4), 421- 444.

Collier, P. ve J. Venables (2007), "Rethinking Trade Preferences: How Africa Can Diversifiy its Export", The World Economy, 30 (8), 1326-1345.

Daude, C., A. Nagengast, J. R. Perea (2015), “Productive Capabilities: An Empirical Analysis of Their Drives", The Journal of International Trade\&Economic Development, DOI: 10.1080/09638199.2015.1073342.

Delice, G. ve Y. E. Birol (2011), “Dolaysız Yabancı Sermaye Yatırımları ve Dış Ticaret Bilançosu: Türkiye Üzerine Bir Uygulama”, Uludağ Üniversitesi İktisadi ve İdari Bilimler Dergisi, 30(2), 1-28. 
Doğan, B. ve M. Can (2016), “Küreselleşmenin Büyümeye Etkisi: Güney Kore Örnekleminde Eşbütünleşme Analizi" Çankırı Karatekin Iktisadi ve İdari Bilimler Fakültesi Dergisi, http://dx.doi.org/10.18074/cnuiibf.319.

Dreher, A. (2006), "Does Globalization Affect Growth? Evidence from a New Index of Globalization", Applied Economics, 38(10), 1091-1110.

Erkan, B. ve E. Yıldırımcı (2015), "Economic Complexity and Export Competitiveness: The Case of Turkey", Procedia-Social and Behavioral Sciences, 195, 524-533.

Felipe, J., U. Kumar, N. Usui ve A. Abdon, (2013), "Why has China Succeeded? and Why It Will Continue To Do So", Cambridge Journal of Economics, 37, 791-818.

Felipe, J., U. Kumar, N. Usui, A. Abdon ve M. Bacate (2012). “Product Complexity and Economic Development", Structural Change and Economic Dynamics, 23, 36-68.

Gorodnichenko, Y., J. Svejnar ve K. Terrell (2007), “Foreign Direct Investment Spillovers in Emerging Market Economies", Ed. Klaus Liebscher, Josef Chirtl, Peter Mooslechner, Doris Ritzberger-Grunwald, Foreign Direct Investment in Europe, Cheltenham: Edward Elgar Publishing Limited, 58-75.

Gregory, A. W. ve B. E. Hansen (1996), "Residual-Based Tests for Cointegration in Models with Regime Shifts", Journal of Econometrics, 70 (1), 99-126.

Hartmann, D., M. R. Guevara, C. Jara-Figueroa, M. Aristaran ve C. A. Hidalgo (2015), "Linking Economic Complexity, Institutions and Income Inequality", http://arxiv.org/abs/1505.07907, (Erişim: 02.11.2015).

Hausmann, R. ve B. Klinger (2009), "Policies for Achieving Structural Transformation in the Caribbean", Inter-American Development Bank, Private Sector Development Discussion Paper, No.2.

Hausmann, R. ve C. A. Hidalgo (2011) "The Network Structure of Economic Output", Journal of Economic Growth, 16(4), 309-342.

Hausmann, R., C. A. Hidalgo, S. Bustos, M. Coscia, S. Chung, J. Jimerez, A. Simoes ve M. A. Yıldırım (2011), The Atlas of Economic Complexity: Mapping Paths to Prosperity, Center for International Development at Harvard University and Macro Connections MIT Media Lab.

Hausmann, R., J. Hwang ve D. Rodrik (2007), "What You Export Matters", Journal of Economic Growth, 12(1), 1-25.

Hidalgo, C. A. (2009). "The Dynamics of Economic Complexity and the Product Space Over a 42 Year Period”, Harvard University CID Working Paper, No.189.

Jankowska, A., A. J. Nagengast ve J. R. Perea (2012), "The Middle-Income Trap: Comparing Asian and Latin American Experiences", OECD Development Center, Policy Insights, No.96. 
Javorcik, B. S. ve M. Spatareanu (2005), "Disentangling FDI Spillover Effects: What Do Firm Perception Tell Us?", Ed. Theodore H. Moran, Edward M. Graham ve Magnus Blomström, Does Foreign Direct Investment Promote Development?, Washington: Institute for International Economics and the Center for Global Development, 45-71.

Karluk, R. S. (2003), Uluslararası Ekonomi Teori ve Politika, Beta Yayınları, İstanbul.

KOF Globalization, http://globalization.kof.ethz.ch/, (Erişim: 15.11.2015).

Lall, S. (2000), "The Technological Structure and Performance of Developing Country Manufactured Exports, 1985-1998", Quenn Elizabeth House University of Oxford Working Paper Series, No. 44.

Lee, J. ve M. C. Strazicich (2003), "Minimum Lagrange Multiplier Unit Root Test with Two Structural Breaks", The Review Of Economics And Statistics, 85(4), 1082-1089.

Maki, D. (2012), "Tests For Cointegration Allowing For an Unknown Number of Breaks", Economic Modelling, 29(5), 2011-2015.

McMillan M., D. Rodrik ve I. Verduzco-Gallo (2014), "Globalization, Structural Change, and Productivity Growth, with an Update on Africa", World Development, 63, 11-32.

OECD (2009), OECD Reviews of Innovation Policy: Korea, OECD Publications.

Poncet, S. ve F. S. Waldemar (2013), "Export Upgrading and Growth: The Prerequisite of Domestic Embeddness", World Development, 51, 104-118.

Prasad, E. S., K. Rogoff, S. Wei ve M. A. Kose (2003), "Effects of Financial Globalization on Developing Countries: Some Emprical Evidence", IMF Occasional Paper, No. 220.

Rao, B. B. ve K. C. Vadlamannati (2011), "Globalization and Growth in the Low Income African Countries with the Extreme Bound Analysis", Economic Modelling, 28, 795805.

Shahbaz, M., S. Khan ve M. I. Tahir (2013), "The Dynamic Links Between Energy Consuption, Economic Growth, Financial Development and Trade in China: Fresh Evidence from Multivariate Framework Analysis", Energy Economics, 40, 8-21.

Shaikh, F. M. ve M. A. Shah (2008), "Impact of Globalization on Pakistan's Economy by Using CGE Model", International Conference on Applied Economics - ICOAE, 839-845.

Villaverde, J. ve A. Maza (2011), "Globalization, Growth and Convergence", World Economy, 34(6), 952-971.

Wang, C., X. Liu and Y. Wei (2004), "Impact of Openness on Growth in Different Country Groups", The World Economy, 24(4), 567-585.

Westerlund, J. ve D. Edgerton (2006), "Simple Tests for Cointegration in Dependent Panels with Structural Breaks", Lund University Department of Economics Working Papers, 13. 
Yameogo, N. D., T. Nabassaga ve M. Ncube (2014), "Diversification and Sophistication of Livestock Products: The Case of African Countries", Food Policy, 49, 398-407.

Yanar, R. ve A. Şahbaz (2013) "Gelişmekte Olan Ülkelerde Küreselleşmenin Yoksulluk ve Gelir Eşitsizliği Üzerindeki Etkileri", Eskişehir Osmangazi Üniversitesi iiBF Dergisi, 8(3), 55-74.

Zivot, E. ve D. W. K. Andrews (1992), "Further Evidence on the Great Crash, the Oil Price Shock and the Unit Root Hypothesis", Journal of Business And Economic Statistics, 10(3), 251-270. 